\title{
МОВА В ДІАЛОЗІ КУЛЬТУР
}

Отримано: 14 лютого 2020 року

Прорецензовано: 17 лютого 2020 року

Прийнято до друку: 20 лютого 2020 року

e-mail: hubinaalla@ukr.net

alla-mart@ukr.net
Губіна А. М., Мартинюк А. П. Особливості європейського освітнього процесу і системи оцінювання навчальних досягнень студентів з іноземних мов у вищій школі (на прикладі Польщі). Наукові записки Національного університету «Острозька академія»: серія «Філологія». Острог: Вид-во НаУОА, 2020. Вип. 10(78). С. 176-180.

DOI: $10.25264 / 2519-2558-2020-10(78)-176-180$

УДК: $81: 378.1$

Губіна Алла Михайлівна,

кандидат психологічних наук, доцент кафедри української та іноземної лінгвістики,

Луиький начіональний технічний університет, м. Луиьк

Мартинюк Алла Петрівна,

кандидат педагогічних наук, дочент кафедри украӥнської та іноземної лінгвістики,

Луиький національний технічний університет, м. Луцььк

\section{ОСОБЛИВОСТІ СВРОПЕЙСЬКОГО ОСВІТНЬОГО ПРОЦЕСУ І СИСТЕМИ ОЦІНЮВАННЯ НАВЧАЛЬНИХ ДОСЯГНЕНЬ СТУДЕНТІВ 3 ІНОЗЕМНИХ МОВ У ВИЩЙ ШКОЛІ} (НА ПРИКЛАДІ ПОЛЬЩІ)

У статті висвітлено специфіку освітнього процесу у польських закладах вищзӧ освіти. 3'ясовано особливості вступної кампанії, структуру семестрів, основні види та форми занять стаціонарного та заочного навчання.

Обірунтовано поетапне здобуття освіти у вищій школі Польщі відповідно до європейських наукових традичій: бакалавр магістр - доктор. 3'ясовано обставини для відрахування студента з вищого навчального закладу. Охарактеризовано відмінності між польською та українською системою вищої освіти. Проаналізовано систему та види оцінювання навчальних досягнень студентів з іноземних мов. Визначено особливості сертифікації оцінювання рівня володіння іноземними мовами студентів в університетах Польиі.

Ключові слова: освітній прочес, Польщ̧а, ECTS (European Credit Transfer System), оцінювання навчальних досягнень, вищза школа, університет, сертифікація, іноземна мова.

\section{Alla M. Hubina,}

PhD (Psychology), associate professor,

Lutsk National Technical University, Lutsk

Alla P. Martyniuk,

PhD (Pedagogy), associate professor,

Lutsk National Technical University, Lutsk

\section{FEATURES OF THE EUROPEAN EDUCATION PROCESS AND SYSTEMS FOR EVALUATING STUDENTS' ACHIEVEMENTS IN FOREIGN LANGUAGES AT HIGHER SCHOOL (ON THE EXAMPLE OF POLAND)}

The article highlights a specific character of the educational process at universities in Poland. The features of the university admission campaign, a semester structure, the main types and forms of the full-time and part-time learning are clarified.

The gradual gain of education at Polish universities is justified by the European scientific traditions: bachelor-master-doctor. The circumstances for expelling a student from a university have been studied. The differences between Polish and Ukrainian higher education systems are characterised. The system and types of evaluation of students' academic achievements in foreign languages are analysed. Innovations in assessing students' knowledge of foreign languages at universities in Poland include self-assessment, the use of computer technology, and portfolio. The peculiarities of the certification of students' foreign language proficiency assessment at universities in Poland are determined. Polish universities are very open and attractive to Ukrainians due to their affordability, countries ' proximity, similarity of languages and the ample opportunities for learning Polish in Ukraine.

The analysis of the theoretical sources of this problem indicates the conformity of the educational process at Polish universities with European requirements, the European credit system ECTS, which aims to take into account students' achievements in mastering the educational program. Polish students have the opportunity to participate in international exchange programs or enter the universities in the European Union under the simplified procedure.

The integration of Poland into Euro-Atlantic and European structures meets the latest requirements of modern European history and plays an important role in the processes of world integration and globalization.

Key words: educational process, Poland, ECTS (European Credit Transfer System), assessment of academic achievement, higher education, university, certification, a foreign language.

Постановка проблеми у загальному вигляді та ї̈ зв'язок із важливими науковими чи практичними завданнями. У 1999 році Болонська декларація, підписана 29 міністрами освіти країн Європи, започаткувала створення Європейського 
простору вищої освіти. Трирівнева система вищої освіти Польщі органічно увійшла в цей простір та передбачає поетапне здобуття освіти в університетах цієї країни. Приєднання Польщі на початку XXI ст. до Болонського процесу і вступ до СС на державному рівні дав змогу цій країні реалізувати стратегічні цілі, що в цілому відображає загальноєвропейську політику розвитку освіти. Введення Болонської системи у Польщі насамперед передбачало підвищення конкурентоспроможності університетів та підняття рівня вищої освіти [10].

Інтеграція Польщі у євроатлантичні та європейські структури, на думку К. Бінницької, відповідає новітнім вимогам сучасної національної і європейської історії, а також є невід’ємною подією у процесах світової інтеграції та глобалізації [2, c. 183]. Для українських студентів університети Польщі стали відкритими й привабливими, що зумовлено такими чинниками як: цінова доступність, сусідство країн, близькість мов, можливість вивчення польської мови в Україні [15].

Аналіз останніх досліджень і публікацій, в яких започатковано розв'язання даної проблеми. В українському науковому просторі проблеми вищої освіти Польщі висвітлено у працях А. Василюк, Л. Гриневич, А. Каплун, С. Коваленко, I. Ковчиної, С. Когут, Н. Никало, Г. Ніколаї, В. Пасічника, В. Ханенко, І. Шемпрух та ін. [1, с. 88].

Вивчення та детальний аналіз наукових публікацій з означеної проблеми дали змогу виокремити ії основні аспекти: компаративний аналіз особливостей в освітніх системах України й Польщі (Ф. Андрушкевич) [1]; соціально-економічні трансформації в Республіці Польща (К. Бінницька) [2]; тенденції децентралізації управління освітою сучасної Польщі (Л. Гриневич) [4]; особливості оцінювання знань студентів з іноземної мови у Польщі (Л. Загоруйко, Н. Шеверун) [7;16]; базові принципи освіти Польщі (Є. Співаковська, Р. Хоменко) [13].

Економічні аспекти децентралізації управління освітою в Польщі знайшли відображення в дослідженнях Я. Герчинського та Т. Левітаса. Проблеми демократизації системи освіти, перспективні теорії виховання і навчання, основи дидактики відображають праці Ч. Купісевіча, Ч. Майорека, В. Оконя, Е. Путкевіч, Б. Суходольського, А. Яновського й та ін. [4, с. 2].

Формулювання цілей статті, постановка завдань. Мета статті - здійснити теоретичний аналіз особливостей освітнього процесу у польських закладах вищої освіти. Завдання статті: з'ясувати специфіку організації освітнього процесу в університетах Польщі; проаналізувати систему та види оцінювання навчальних досягнень студентів з іноземних мов.

Виклад основного матеріалу дослідження. Для досягнення Болонської угоди Польщею було здійснено низку кроків, зокрема:

- запроваджено у масову практику використання Додатку до диплому, що місить інформацію про навички, отримані під час навчання;

- розроблено систему дворівневої освіти;

- запроваджено систему ECTS в оцінюванні навчальних досягнень студента;

- зорганізовано мобільність польських студентів, головним чином в межах програми Erasmus;

- створено РКА (Державний Акредитаційний Комітет) - відповідальний орган за якість навчання у польських університетах [5, с. 140].

Здійснюючи загальний огляд системи вищої освіти Польщі, зауважимо, що перший університет у м. Кракові було засновано ще 1364 р. У Варшаві університет діє з 1816 р, політехнічний інститут - 1826 р. Розвиток вищої школи ознаменувався двома періодами повоєнних років XX століття: німецькою, радянською. За умов соціалістичного ладу державна вища освіта в Польщі була безкоштовною. Сдиним великим недержавним закладом освіти був Люблінський католицький університет.

Суспільно-політичні зміни в державі, впровадження ринкової економіки спонукали і до реформи вищої освіти: освітні заклади отримали значно вищий рівень автономії, право приймати частину студентів з оплатою навчання; урізноманітнився перелік спеціальностей; з'явилися приватні заклади вищої освіти.

М. Гагарін зазначає, що Польща має 11 державних та 1 приватний університети класичної моделі, 15 технічних університетів і 2 інститути, 6 академій економіки, 11 медичних академій, 17 шкіл мистецтв і 6 вищих закладів навчання 3 фізкультури і спорту. Список недержавних 3ВО включав вже 84, з яких 9 мали право надавати кваліфікацію «магістр» [6, с. 59].

Система освіти в Польщі фінансується державою. Закон про освіту 1991 року забезпечує всіх учнів і студентів, включаючи й тих, що мають спеціальні освітні потреби, правом на освіту на всіх рівнях. Освітні органи влади також зобов'язані направляти дітей з фізичними вадами в загальні школи відповідно до бажань їхніх батьків і потреб дітей. Батьки учнів та студентів-осіб з інвалідністю, влаштованих у спеціальні шкільні центри, мають право на фінансову підтримку від органів державної влади на покриття додаткових витрат, які з цим пов'язані. Те саме стосується спеціальних професійних тренінгів для дорослих людей з вадами [11, с. 126].

Як зазначалося, Польща входить до Болонської системи, і має трьохступеневу систему вищої освіти. На кожному 3 етапів навчання студенти вивчають відповідні освітні програми, і за умови виконання програмних вимог (здача іспитів, написання, захист письмових та наукових робіт), їм присвоюється ступінь бакалавра або бакалавра-інженера, магістра, науковий ступінь доктора відповідно (табл. 1) [9]. Специфіку вищої освіти в Польщі подано в табл. 2.

Система освіти в Польщі

Таблиия 1

\begin{tabular}{|c|c|c|c|}
\hline Рівні вищої освіти & I рівень & II рівень & III рівень \\
\hline \multirow[t]{2}{*}{$\begin{array}{l}\text { Ступінь } \\
\text { та тривалість } \\
\text { навчання }\end{array}$} & $\begin{array}{l}\text { Бакалавр (BA, licencjat) - } 3 \text { роки (6 } \\
\text { семестрів) } \\
\text { Бакалавр-інженер (BSc, Inzyneir) - } \\
3,5 \text { роки ( } 7 \text { семестрів) }\end{array}$ & $\begin{array}{l}\text { Магістр (MA, Magister) - } 2 \text { роки (4 } \\
\text { семестри) } \\
\text { Магістр (MA, Magister) - } 1,5 \text { роки (3 } \\
\text { семестри) }\end{array}$ & Доктор (PhD, Doctor) \\
\hline & \multicolumn{2}{|c|}{ Неподільна магістратура -5 років (10 семестрів) } & \\
\hline
\end{tabular}

[джерело: 9] 
Основні особливості вищої освіти в Польщі

Таблиия 2

\begin{tabular}{|c|c|}
\hline Освітні компоненти & Характеристики освітнього процесу \\
\hline Вступна кампанія & $\begin{array}{l}\text { Дворазовий прийом абітурієнтів: на зимовий (з } 1 \text { жовтня) та літній (з березня) семестри на- } \\
\text { вчання. }\end{array}$ \\
\hline Назва закладу освіти & $\begin{array}{l}\text { Університет, технічний університет, економічний університет, політехніка, академія або ви- } \\
\text { щою школою (залежно від того, якими повноваженнями наділений заклад освіти). }\end{array}$ \\
\hline Навчальний рік & $\begin{array}{l}\text { Два семестри навчання (по } 15 \text { тижнів кожен). Один тиждень складається з } 30 \text { годин навчаль- } \\
\text { них занять. }\end{array}$ \\
\hline Зимовий семестр & $\begin{array}{l}\text { Структура - } 15 \text { тижнів навчання, різдвяні канікули, зимова сесія та зимові канікули. Почина- } \\
\text { ється } 1 \text { жовтня, закінчується - в середині лютого наступного календарного року. }\end{array}$ \\
\hline Літній семестр & $\begin{array}{l}\text { Структура - } 15 \text { тижнів навчання, Великодні свята, літній період навчання, літні канікули. По- } \\
\text { чаток навчання - середина лютого, закінчення - } 30 \text { вересня. }\end{array}$ \\
\hline Система оцінювання & $\begin{array}{l}\text { 5-бальна система оцінювання: } \\
\text { 2-2,5 бали (відповідає F-FX оцінці-ECTS) - незадовільно; } \\
3 \text { бали (Е) - достатньо; } \\
3,5 \text { (D) бали - задовільно; } \\
4 \text { (С) бали - добре; } \\
\text { 4,5 (В) - дуже добре; } \\
5 \text { (А) - відмінно. }\end{array}$ \\
\hline Форми проведення занять & Лекції, практичні заняття, семінари, лабораторні заняття, конференції, дискусії. \\
\hline $\begin{array}{l}\text { Стаціонарна (денна) форма } \\
\text { навчання }\end{array}$ & $\begin{array}{l}\text { Заняття проходять } 3 \text { понеділка по п'ятницю. Один день в тижні, як правило, виділяється для } \\
\text { самостійної роботи студентів. }\end{array}$ \\
\hline Заочна форма навчання & $\begin{array}{l}\text { Заняття проходять в суботу і неділю протягом всього дня, кожні два тижні. Буває, що заняття } \\
\text { можуть починатися в п’ятницю ввечері або закінчуватися в понеділок ввечері. }\end{array}$ \\
\hline $\begin{array}{l}\text { ECTS (European Credit } \\
\text { Transfer System) }\end{array}$ & $\begin{array}{l}\text { Загальноєвропейська система кредитування, що має на меті облік досягнень студентів при } \\
\text { освоєнні навчальної програми впродовж визначеного періоду. Завдяки цій системі, студенти } \\
\text { мають можливість приймати участь в міжнародних програмах обміну, а випускники вступами } \\
\text { на навчання в університети інших країн Європи за спрощеною процедурою. }\end{array}$ \\
\hline
\end{tabular}

Основними формами проведення навчальних занять в університетах Польщі $\epsilon$ - wykłady (лекціï), ćwiczenia (практичні), seminarium. Для отримання допуску до сесії, необхідно мати достатню кількість відвідувань 3 кожного предмету. У випадку трьох прогулів студент не допускається до здачі екзамену - warunek. В залежності від навчального закладу, протягом одного семестру, студентові дозволяється отримати в середньому до двох «варунків». В іншому випадку студент постане перед вибором: забрати документи або повторювати рік з початку (платно) [8].

Оцінювання рівня знань студентів у польських університетах відбувається за шкалою: 5 - відмінно; 4.5 - дуже добре; 4 - добре; 3.5 - середньо; 3 - задовільно; 2 - незадовільно.

Студент має право перездачі іспиту упродовж двох наступних сесій. У разі негативного результату, може виникати питання про відрахування [12].

Назвемо обставини для виключення студента з навчального закладу:

- часті пропуски занять без поважної причини;

- недотримання крайніх термінів здачі запланованих робіт (курсова робота, дипломна робота, дослідницьке завдання , іспит);

- одне грубе порушення або систематичні незначні порушення правил поведінки в установі;

- неоплачений семестр.

Зауважимо, керівництво вищих навчальних закладів Польщі доволі лояльно ставиться до студентів-іноземців, проте, краще дотримуватися вимог, викладених вище. Також, студентам надається можливість одночасно навчатись та працювати при умові легального працевлаштування. Студентам стаціонару немає потреби у ніяких додаткових дозволах, студентам інших форм навчання необхідно працевлаштовуватись за наявності запрошення або дозволу на роботу. У разі порушення умов працевлаштування, студента можуть депортувати з країни без права в'їзду на територію Європейського Союзу протягом декількох років, також його виключають з ЗВО без права поновлення [12].

До інновацій в оцінюванні навчальних досягнень студентів з іноземних мов в університетах Польщі можна віднести самооцінювання, використання ІКТ, портфолійне оцінювання.

Самооцінювання (autoewaluacja) знань студентами сприяє розвитку внутрішньої мотивації до навчання. Найпоширенішим видом самооцінювання студентів є тестування з використанням комп’ютерної техніки. Досвід використання комп'ютерних технологій у процесі вивчення іноземних мов в університетах Польщі свідчить, що завдяки застосуванню комп'ютерів під час занять можна виявляти резерви навчального процесу, особистості студента; збільшуються дидактичні можливості викладача [16].

Портфоліо виступає важливим засобом оцінювання, яке передбачає зібрання студентських робіт з певної дисципліни. $€$ два види портфоліо: 1) портфоліо розвитку; 2) демонстраційне портфоліо (зразки кращих робіт студента). Портфоліо може продемонструвати: індивідуальний рівень і темп навчальної діяльності; рівень партнерства викладача і студента; розвиток навичок самооцінювання; найкращу роботу студента на певному етапі; стан успішності для батьків та інших зацікавлених осіб [7, с. 341].

Особливістю оцінювання рівня володіння іноземними мовами студентів в університетах Польщі є сертифікація. Умовою отримання сертифікату є складання іспиту з іноземної мови на рівні В2 відповідно до Загальноєвропейських рекомендацій з мовної освіти, який проводять наприкінці семестру як в зимовій, так і в літній сесії. Іспит складається 3 двох частин: 
письмової та усної. Письмова частина триває до 120 хвилин і надає можливість одержати максимально 80 балів. Структура письмового іспиту: розуміння тексту на слух, розуміння прочитаного тексту, функціональне використання граматичних структур і словникового запасу, письмо. Усна частина триває до 15 хвилин і надає можливість отримати максимально 20 балів. Оцінка за іспит є результатом суми балів з обох частин [19].

Підрозділи навчання іноземних мов в університетах Польщі крім обов'язкових занять з іноземних мов, пропонують також додаткові курси, які надають можливість студентам усіх факультетів вивчати додатково іноземні мови. Закінчивши курс французької мови, студенти можуть отримати такі сертифікати: «Диплом спілки французької мови в Парижі» (Diplôme de Langue de l'Alliance Française de Paris) чи «Диплом вивчення французької мови» (Diplôme d'Etudes en Langue Française (DELF); під час вивчення німецької мови такі сертифікати: «Сертифікат німецької мови» (ZD - Zertifikat Deutsch), «Cepтифікат середнього рівня володіння німецькою мовою» (MD - Mittelstufe Deutsch), «Сертифікат німецької мови для економістів» (Wirtschaftssprache Deutsch). При університетах працюють Британські центри (British Centre) та Центри Гердера (Centrum Herdera), які пропонують скласти такі іспити: сертифікат німецької мови (Zertifikat Deutsch), основний екзамен середнього рівня (Zentrale Mittelstuffenprüfung), диплом німецької мови вузького напрямку (Kleines Deutsches Sprachdiplom), міжнародний екзамен з німецької мови для економістів (Prüfung Wirtschaftsdeutsch International) [18].

Демократизація початку 90-х років супроводжувалася істотною децентралізацією. Сьогодні заклади вищої освіти часто здійснюють міжнародні контакти і проєкти поза міністерствами. Нова Польща докладає значних зусиль для об'єднання і підтримки своєї діаспори. Оскільки останнім часом про польські заклади освіти можна знайти чимало інформації у міжнародних виданнях і базах даних, то варто надіслати запит безпосередньо до обраного навчального закладу.

Польща є однією з найактивніших учасниць нових проєктів, тому, зазвичай, визнає ті атестати, які у країні їхнього присудження після 12-13-річної середньої освіти надають власнику право претендувати на вступ до закладів університетського рівня. Польща підписала практично всі європейські конвенції з порівняння і визнання освітніх кваліфікацій, має великий пакет двосторонніх угод.

Визнаються у Польщі періоди розпочатої за кордоном вищої освіти, якщо кандидат має усі необхідні докази їхнього успішного завершення.

У випадках належної оплати програми навчання і виконання вказаних вище кваліфікаційних вимог, вища освіта Польщі практично повністю відкрита для студентів-іноземців. Тим, хто бажає навчатися, чи продовжувати освіту на мистецьких i спортивних спеціалізаціях, необхідно скласти спеціальні тести для демонстрування належних здібностей, а також (за вимогою) подати зразки свого творчого доробку.

Достатнє знання польської мови є обов'язковою умовою для допуску. Успішного навчання на річних мовних курсах та складання заключних екзаменів, зазвичай, цілком достатньо для вступу і початку навчання на першому циклі польських закладів університетського рівня. Його можуть засвідчити амбасади і консульства. У разі необхідності вивчення мови кандидат повинен звернутися чи у заклад вищої освіти, чи в мовний центр у м. Лодзь, аби за 9 місяців занять по 20 годин мови щотижня підготуватися до складання екзаменів і навчання. Дисертації вищого рівня дозволено писати і захищати найбільш вживаними іноземними мовами (англійською, німецькою, французькою чи російською). Останнім часом спостерігається дедалі більше прикладів застосування цього правила до магістерських тез. Щодо докторських студій, то кандидат повинен звертатися до польського закладу, який має право їх проводити. Зарахування відбувається на наявні місця, зважаючи на півень академічної кваліфікації претендента, яка повинна бути не нижчою магістра у Польщі. Найкращі заклади вищої освіти країни: Варшавський університет, Національний Вроцлавський університет, Ягелонський університет [6, с. 61].

У Польщі є можливість навчатись англійською мовою. Вартість навчання англійською мовою здебільшого є вищою. Для того, щоб навчатись у польському ЗВО, на момент вступу потрібно знати мову, принаймні, на початковому рівні. Польська мова не є складною для вивчення, оскільки українська мова за багатьма рисами більше наближена до польської, аніж, навіть, до російської [17]. На рівень А1 мову можна вивчити за 50 занять, відвідуючи курси та самостійно читаючи літературу. Студенти-іноземці, перебуваючи у мовному середовищі, швидко адаптуються і вдосконалюють рівень володіння мовою. Значна частина українських студентів, що вже навчаються в Польщі, володіють польською мовою на початковому або середньому рівні. Під час навчання, в деяких навчальних закладах, іноземні студенти можуть відвідувати заняття 3 польської мови. Окрім того, у Польщі $є$ можливість навчатись англійською мовою (значно меншою $є$ пропозиція навчання французькою, німецькою мовами). При вступі абітурієнт повинен показати документ, що підтверджує знання англійської мови (міжнародний тест) або написати тест з англійської мови у навчальному закладі. Увесь процес навчання відбувається англійською мовою: лекції, практичні заняття, іспити, написання та захист дипломних робіт. Багато польських студентів обирають навчання англійською мовою [13, с. 144].

SlavicLanguagesCenter проводить набір кандидатів програми «Навчання у Польщі», починаючи з 2010 року. За цей період учасниками програми стали понад 1400 українців [15]. Польські випускники тамтешніх університетів нерідко прагнуть в подальшому шукати більш високооплачувану роботу в країнах Західної Свропи. А ось позитивною стороною життя студентів у Польщі є те, що практично кожен може дозволити собі в канікулярний період мандрівки Свропою, адже молодим людям пропонують безліч акційних пропозицій і лоукостів, що дає можливість за помірні гроші здійснювати досить далекі подорожі [14].

Назвемо відмінності між польською та українською системою освіти:

1. Суттєві відмінності освітніх процесів у двох країнах. Особливо для українських студентів із дипломом бакалавра для отримання у Польщі ступеня магістра.

2. Додатковий місяць канікул у Польщі (навчання розпочинається 1 жовтня) дає можливість краще підготуватись до нового навчального року, відпочити, або ж заробити гроші на подальше навчання.

3. Відмінності в видах та формах навчальних занять. Сесія складається з лекцій. Семінари студенти здають ще до сесійного періоду. Здебільшого в цей період студенти складають тести письмово. Усні оцінювання відбуваються дуже рідко.

4. Наявність у польській освіті єдиної та загальної електронної системи, в якій кожен студент має свій акаунт. Вказана система містить усі дані про навчальні дисципліни, викладачів, розклад, оцінки, контакти одногрупників та багато іншої корисної інформації. 
5. Створення індивідуальної освітньої траєкторії. Кожен студент сам обирає дисципліни, які буде вивчати. Деканат лише визначає перелік «обов'язкових курсів» - які міняти не можна. Дисципліни «на вибір» теж пропонує деканат, але які саме відвідувати - обирає студент самостійно.

6. Викладачі на початку кожного курсу повідомляють студентів, скільки навчальних годин можна пропустити. Надають свої контакти, щоб студенти могли в зручний час з ними зв'язатися.

7. Включення студента в науково-пошукову діяльність одразу після вступу до освітнього закладу. Студенти починають писати наукову роботу з першого курсу навчання. Вони обирають собі керівника, з яким будуть консультуватись протягом усього процесу написання. Захист наукової роботи відбувається на завершальному етапі навчання в закладі.

8. Канікули під час Різдвяних та Великодніх свят дають можливість святкувати їх у сімейному колі [3].

Висновки 3 даного дослідження і перспективи подальших наукових розвідок. Проведений аналіз теоретичних джерел означеної проблеми засвідчує відповідність освітнього процесу в університетах Польщі європейським вимогам, загальноєвропейській системі кредитування ECTS, що має на меті облік досягнень студентів при освоєнні освітньої програми. Польські студенти мають можливість приймати участь в міжнародних програмах обміну, а випускники вступати на навчання в університети ЄС за спрощеною процедурою.

Подальшу наукову перспективу вбачаємо у висвітленні оптимізації шляхів освітнього партнерства волинських та польських вишів.

\section{Література:}

1. Андрушкевич Ф. Компаративний аналіз особливостей освітніх інновацій в освітніх системах України й Польщі. Директор школи, ліщею, гімназії. 2011. № 5. С. 88-92.

2. Бінницька К. Соціально-економічні трансформації в Республіці Польща у ХХ столітті - чинник розвитку системи вищої педагогічної освіти в країні. Психолого-педагогічні проблеми сільської школи. 2012. Вип. 42. С. 176-185.

3. Вища освіта у Польщі. URL:https://kudapostupat.ua/vse-pro-vyshchu-osvitu-u-polshchi/ (дата звернення: 15.01.2020).

4. Гриневич Л. М. Тенденції децентралізації управління базовою освітою в сучасній Польщі. Автореф. дис. ... канд. пед. наук. Київ, 2005. 23 с.

5. Грищук Ю. В. Історико-педагогічний аналіз розвитку освіти в Польщі. Педагогічний процес: теорія $і$ практика. 2015. Вип. 1-2. С. 137-141.

6. Зарубіжна система вищої освіти: навч. посіб. / авт.-упоряд. М. І. Гагарін. Умань : ВПЦ «Візаві», 2017. 102 с.

7. Загоруйко Л. О. Особливості оцінювання знань студентів з іноземної мови у вищих навчальних закладах Польщі. Педагогічні науки: теорія, історія, інноваційні технологіï. 2014. № 8 (42). С. 337-343.

8. Навчальний процес в Польщі. URL:https://edu-solution.com.ua/navchalnyj-protses/ (дата звернення: 23.12.2019).

9. Особливості освіти в Польщі. URL:https://toposvita.com/informator-abit/osoblivosti-osviti-v-polshchi/ (дата звернення: 23.12.2019)

10. Про Болонський процес і вищу освіту в Польщі. URL:http:// www.osvita.org.ua/articles/875.html (дата звернення: 24.12.2019).

11. Сисоєва С. О., Кристопчук Т. С. Освітні системи країн Європейського Союзу: загальна характеристика : навч. посіб. / Київ. ун-т імені Бориса Грінченка. Рівне: Овід, 2012. 352 с.

12. Система оцінювання в польських ВН3. Чи відраховують за неуспішність? URL:https://up-study.ua/uk/posts/sistemaocinjuvannja-v-polskix-vnz-chi-vidraxovujut-za-neuspishnist (дата звернення: 27.12.2019).

13. Співаковська Є. О., Хоменко Р. С. Базові принципи освіти Польщі. Зб. наук. праць Херсон. держ. ун-ту. Педагогічні науки. 2015. Вип. 67. С. 139-148.

14. Українська студентка: «у Польщі більш жорсткі критерії оцінки знань, але стипендії ні в кого не забирають» / URL: (дата звернення: 28.12.2019).

15. Університети та ВНЗ Польщі для українців. URL:https://slavic-center.com.ua/uk/vishha-osvita-v-polshhi/ (дата звернення: 23.12.2019)

16. Шеверун Н. Особливості оцінювання та сертифікації навчальних досягнень студентів з іноземних мов в університетах Польщі URL: http://old.franko.lviv.ua/Pedagogika/periodic/pedos3t/tom1/45_sheverun.pdf (дата звернення: 15.01.2020).

17. Kononenko I. Język ukraiński i polski: studium kontrastywne / Кононенко I. Українська і польська мови: контрастивне дослідження. Warszawa: Wydawnictwa Uniwersytetu Warszawskiego, 2012., 808 s.

18. Przysiężna B. Chys A. Kryteria oceny osiągnięć studentyw politechniky. Świat nauki. 2009. N 9. S.6-11.

19. Ziemnicki S. Ocenianie po nowemu. Edukacja w Europie. 2010. N 1. S. 3-7. 